\title{
Studies on Length-Length Relationship of Cat Fish Mystus armatus from Aurangabad Region
}

\author{
Chhaya Khillare, Smita R. Sonawane \\ Department of Zoology Dr. Babasaheb Ambedkar Marathwada University, Aurangabad (M.S)
}

\begin{abstract}
Mystus armatus commonly called as katarana. The present study aims to analyze the morphometric character of fish. Length frequency distribution, length-length relationships are presented this work. Length- length relationships were estimated by regression equation method. The results indicated that length- length relationship (LLR) was highly co-related, r2>0.71: $p<0.001$. All the morphometric relationships were linear, positive.
\end{abstract}

Keywords: Length-length relationship, Mystus armatus, total length, standard length, fork length, head length, dorsal length

\section{Introduction}

A variety of morphological, physiological, behavioral and biochemical characteristics are used to identify and classify the fishes. In practices though, it is more common to use morphometric measurements (i.e. body length, body depth, head length, eye diameter, jaw length) and meristic (i.e. fin ray, scale, teeth, gill raker, and lateral line pore counts). These morphometric measurements are usually presented as a proportion of standard, fork and total length. (Howe, 2002). Morphometric measurements and statistical relationships of fishes are imperative for both fishery biology (Sparre et. al. 1989; Mustafa \& Brooks 2008) and taxonomy studies (Tandon et al 1993; Simon et al 2010a). It is very important especially in comparative studies which little information seems to be available for fish species (Froese and Pauly, 2005).Length- length relationship help in inter-conversion of total length data with other morphometric characters (Manimeghalai, 2010)

The present study was undertaken with the objective to estimate length- length relationship in fresh water fish $\mathrm{M}$. armatus.

\section{Material and Method}

Fish samples (fishes) were collected randomly from local fish market. Specimens were preserved in 5\% formalin and then identified with the help of Jayaram . Length measurement was taken. Total length was measured from the anterior tip of the longest jaw to the most posterior part of the tail, standard length was measured from anterior tip of the upper jaw to the tip of hypural bone (urostyle), fork length was measured from the anterior tip of upper jaw to the median point of the caudal fin, dorsal length was measured from anterior tip of upper jaw to the posterior end of dorsal fin, head length was measured from anterior tip of upper jaw to posterior endof head (Laevastu, 1965) to the nearest $0.01 \mathrm{~cm}$.

Length-length relationship was qualified according to Pauly (1983) by regression equation, the relationship equation can be summarized by equation from

$Y=a=b X$

Where $\mathrm{x}$ and $\mathrm{y}$ are two variables. $\mathrm{a}$ is intercept and $\mathrm{b}$ is slope or regression coefficient. The degree of association between two variables is expressed as the correlation coefficient $r$, and the coefficient of determination as $r 2$ which is example of degree of variance.

\section{Result and Discussion}

The morphometric measurements are represented in table 1. And table 2 summarizes the result of regression equation

Table1: Morphometric measurements of M. armatus

\begin{tabular}{|c|c|c|c|c|}
\hline \multicolumn{5}{|c|}{$(n=100)$} \\
\hline $\begin{array}{l}\text { Morphometric } \\
\text { Characteristic }\end{array}$ & Min & $\operatorname{Max}$ & Mean $\pm S D$ & $\begin{array}{l}T L \% \\
\text { mean }\end{array}$ \\
\hline Total length & 11.2 & 32 & $17.436 \pm 5.480$ & \\
\hline Standard length & 8.9 & 26.5 & $13.631 \pm 4.7241$ & 78.17 \\
\hline Fork length & 9.9 & 28.1 & $15.015 \pm 5.0697$ & 86.11 \\
\hline Dorsal length & 2 & 10.9 & $4.891 \pm 2.145$ & 28.05 \\
\hline Head length & 1.5 & 11.6 & $3.317 \pm 2.2696$ & 19.02 \\
\hline
\end{tabular}




\section{International Journal of Science and Research (IJSR) \\ ISSN (Online): 2319-7064}

Index Copernicus Value (2013): 6.14 | Impact Factor (2015): 6.391

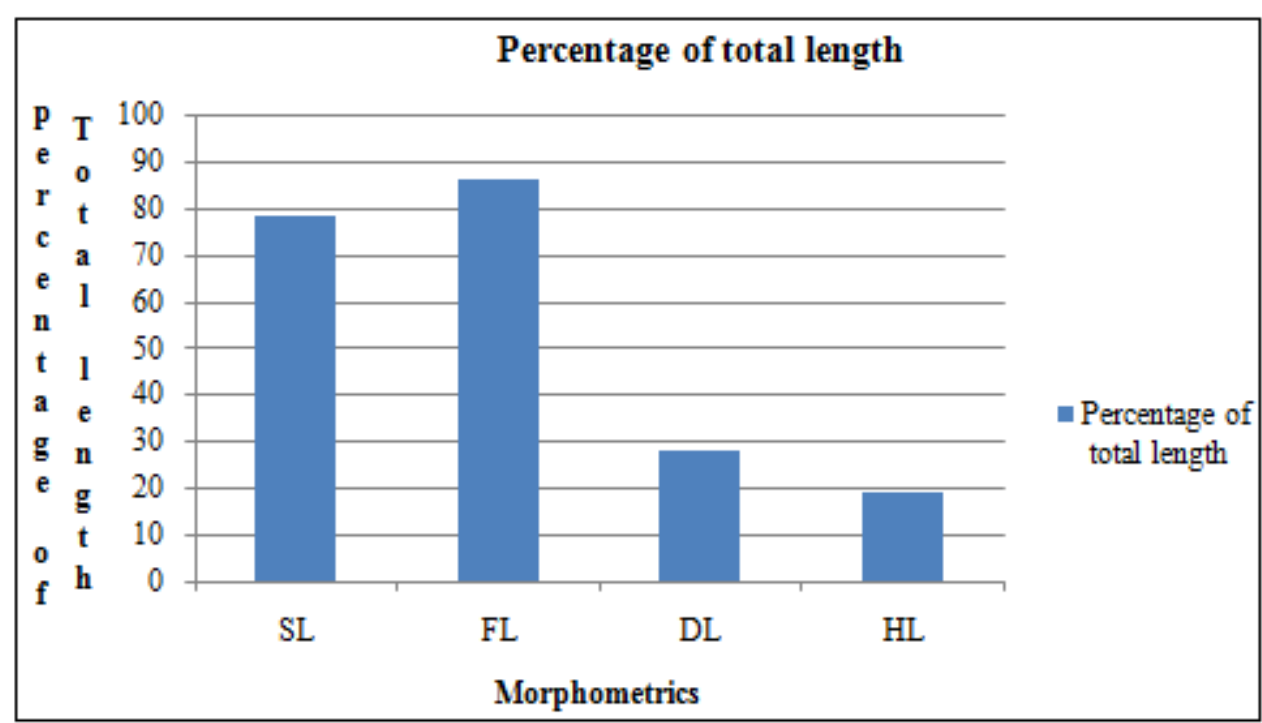

Figure 1: Morphometrics expressed as a percentage total length in M. armatus

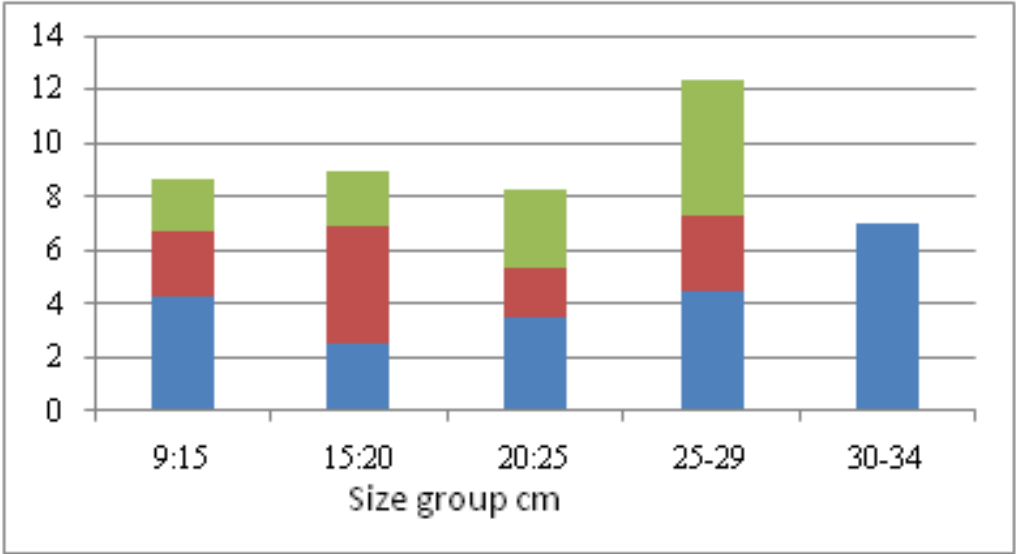

Figure 2: Size frequency distribution of M. armatus

The total length of fish ranged from 11.2 to 32 with the mean and standard deviation $17.436 \pm 5.480$. mean standard length was 13.631 , it was 78.17 percent of total length. The fork length was 86.11 percent to total length whereas dorsal length and head length was 28.05 and 19.02 respectively.

Figure 2 represents the length frequency data. On grouping into 5 groups of $5 \mathrm{~mm}$ length difference.
Table 2: Regression analysis of length-length relationship f

M. armatus
\begin{tabular}{|c|c|c|c|c|c|}
\hline Sr.No & X-Axis & Y-Axis & Y=a+bX & R2 & r \\
\hline 1 & TL & SL & Y=-0.743+0.824X & 0.914 & 0.821 \\
\hline 2 & TL & FL & Y $=-0.439+0.88 X$ & 0.918 & 0.886 \\
\hline 3 & TL & DL & $Y=-0.905+0.332 X$ & 0.713 & 0.332 \\
\hline 4 & TL & HL & Y= $=-2.98+0.361 X$ & 0.752 & 0.36 \\
\hline
\end{tabular}




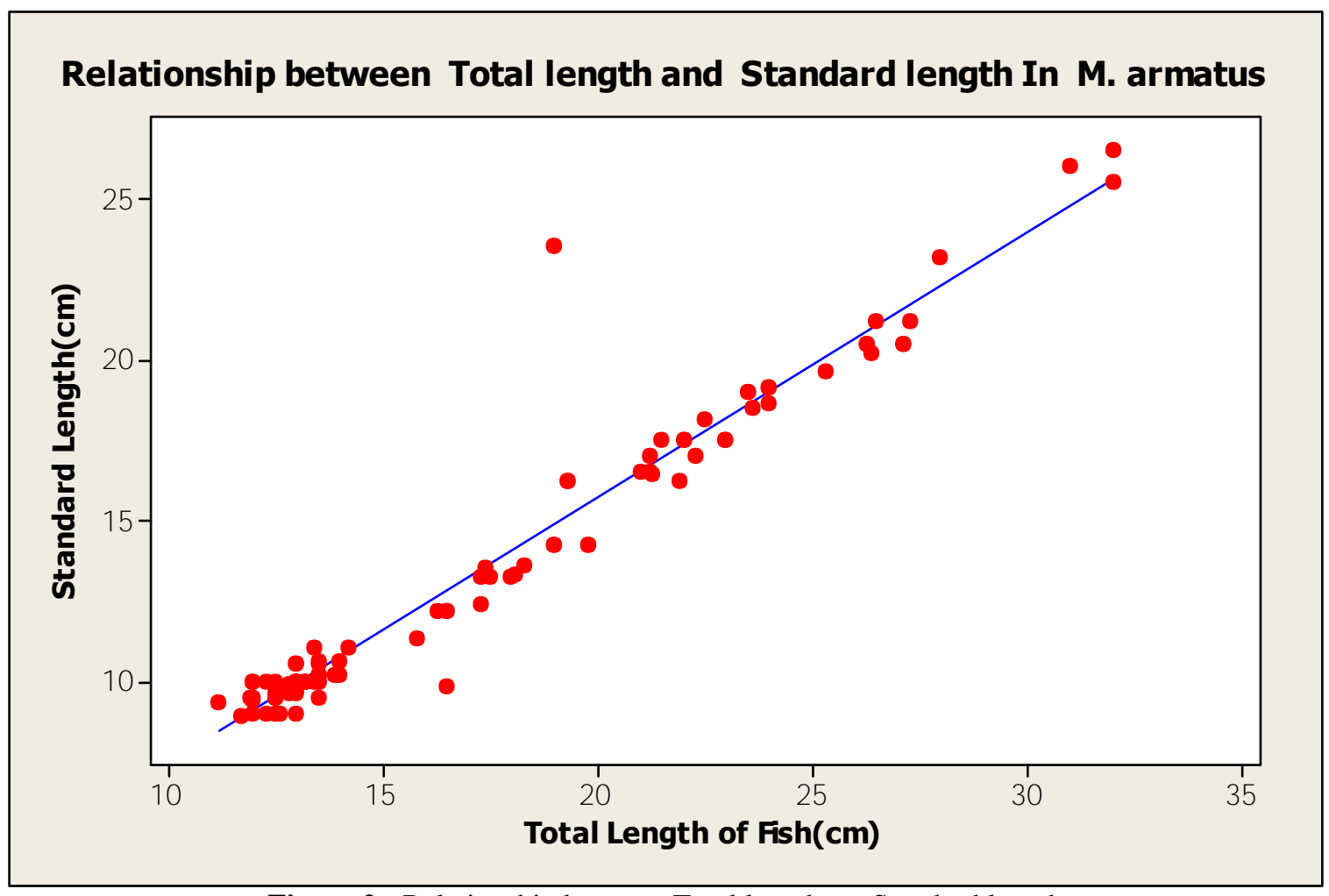

Figure 2: Relationship between Total lengths to Standard length

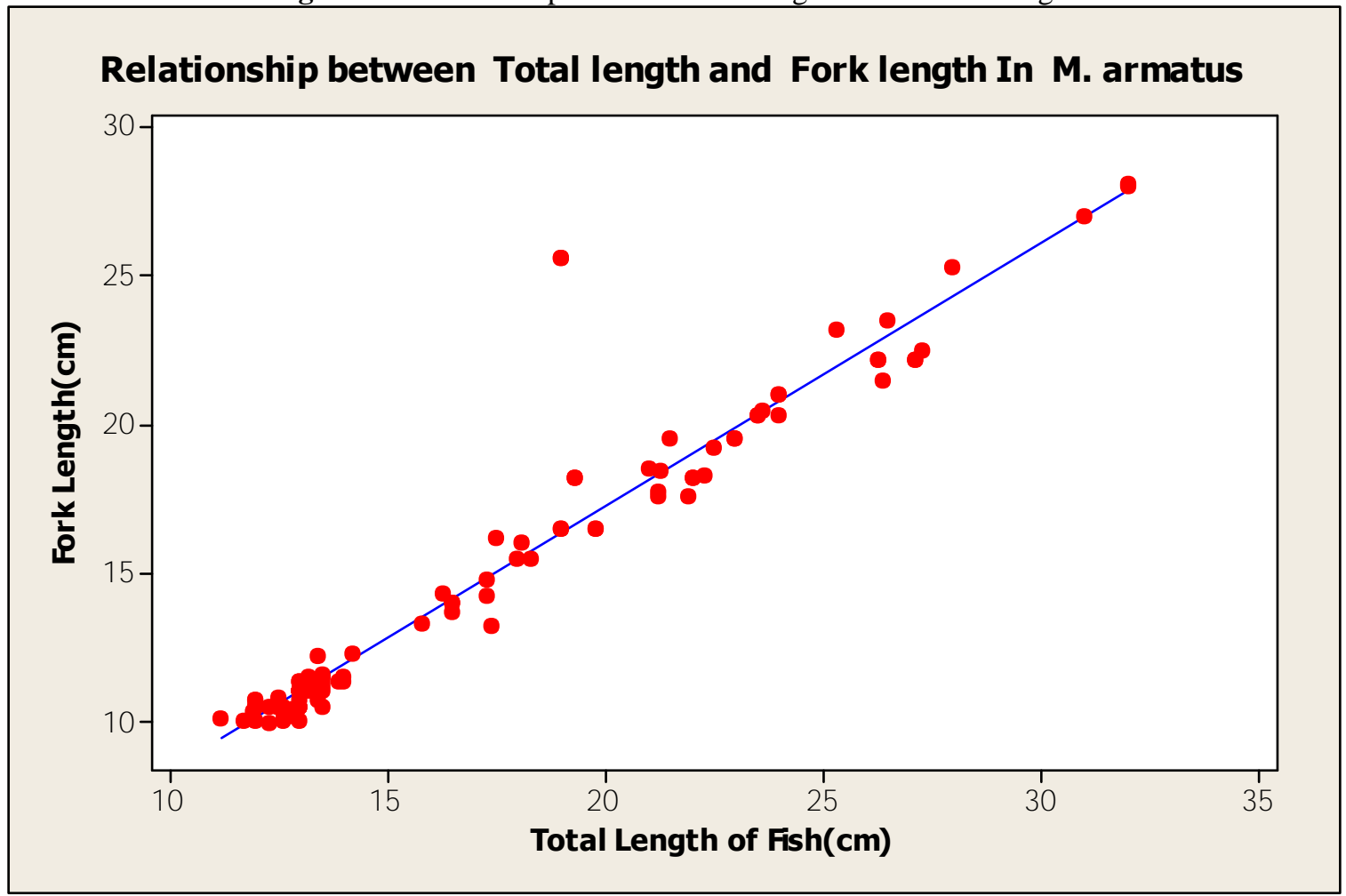

Figure 3: Relationship between Total length to Fork length 


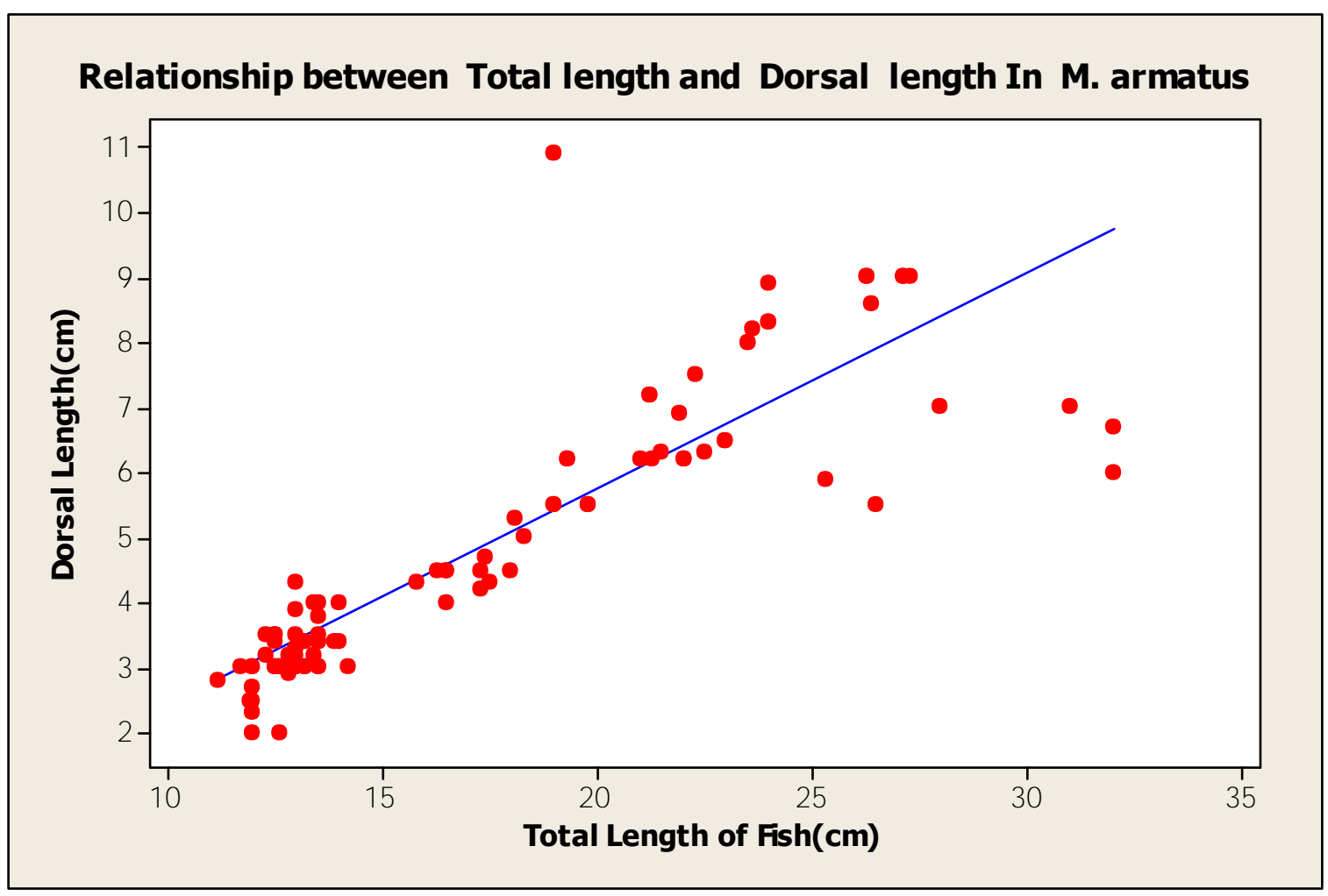

Figure 4: Relationship between Total length to Dorsal length

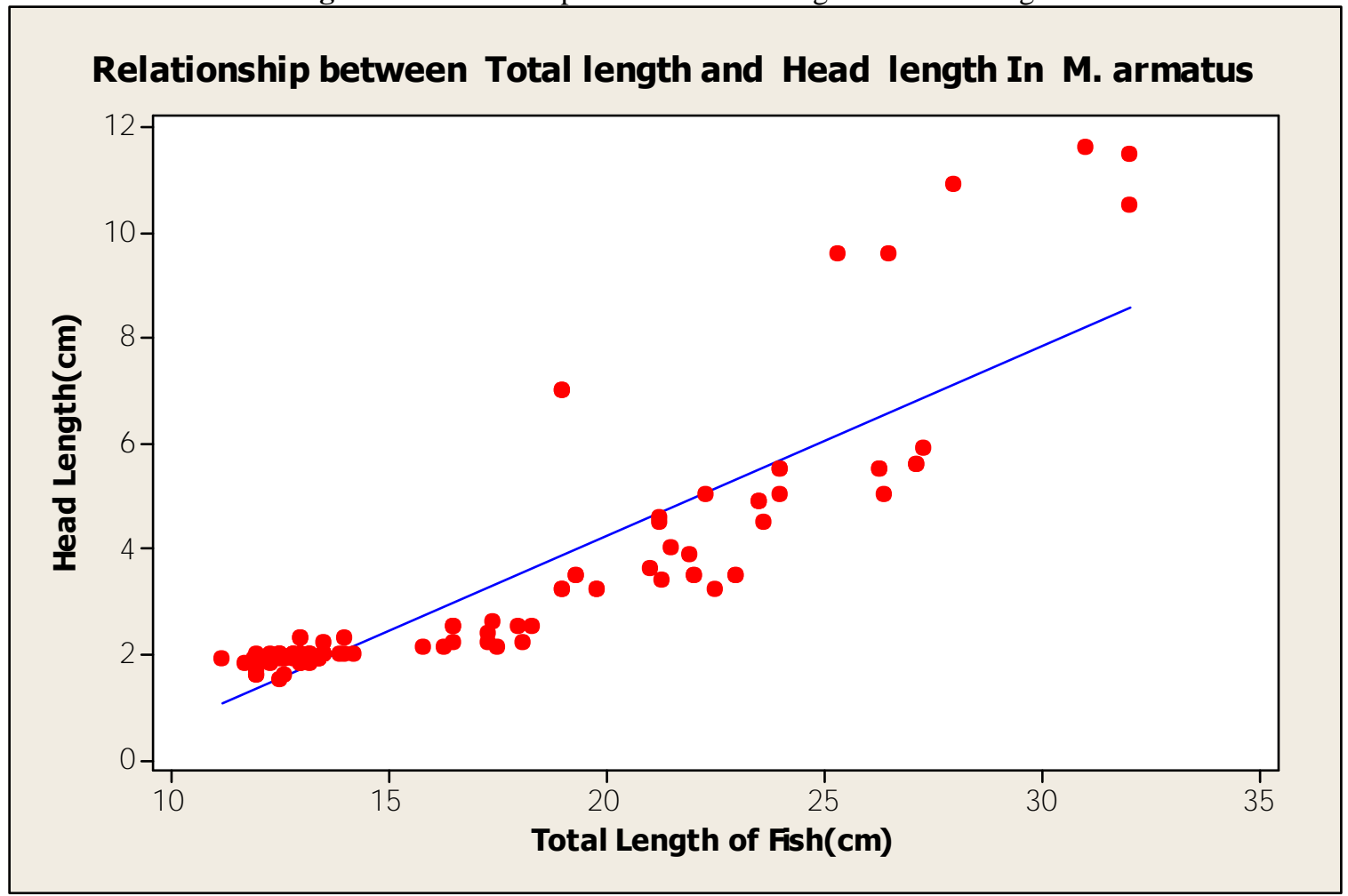

Figure 5: Relationship between Total lengths to Dorsal length

All the observed morphometric characters significance positive correlation. The high values of r2 in length-length relationships indicate that the length relationships are linear over the observed range of values. A number of factors might affect the proportion total length, standard length, fork length, including growth phase, food availability and quality of food, size ranges, health, general fish condition and preservation technique (Gaygusuz et al., 2006). However, these factors were not considered in the present study. the correlation coefficient between total length, fork length standard length, dorsal length and head length were significant. This is an accordance with Hussain (2010) that all LLRs were highly correlated.

\section{References}

[1] Akombo P.M, Akange E.T, Adikwu I.A, Araoye P.A.(2013): Length-weight relationship, condition factor and feeding habits of Synodontis schall (Bloch and Schneider, 1801) In river Benue at Makurdi, 
Nigeria. Journal of Global Biosciences, 3(6), 2014, 890-894

[2] Amtyaz Safi, M. Atiqullah Khan, M. Usman Ali Hashmi and M. Zaheer Khan (2014): Length-Weight relationship and condition factor of striped piggy fish, Pomadasys stridens (Forsskal, 1775) from Karachi Coast, Pakistan. Journal of Entomology and Zoology Studies, 2 (5),2014 25-30.

[3] B.K. Gupta, U.K. Sarkar, S.K. Bharadwaj and A. Pal.(2010): Condition factor, length-weight and length-length relationship of an endangered fish Ompok pabda (Hamilton 1822) (Siluriformes: Siluridae) from the river Gomti, a tributary of the river Ganga, India. Journal of applied Ichthyology.27 (2011), 962-964

[4] Dalie Dominic, Dr. N.D. Inasu and swapana Johny (2013): Studies on length-length relationship of ornamental fish, Etroplus maculatus from KeecheriPuzhakkal river system, Kerala., International journal of innovative research and studies.2(5),2013, 183-193.

[5] F. Percin and O. Akyol.(2009): Length-weight and length-length relation of the blufin tuna, Thunnus thynnus L., in the Turkish part of the eastern Mediterranean Sea. Journal of applied Ichthyology, 25(2009), 782-784.

[6] K. Pervaiz, Z. Iqbal, M.R. Mirza, M.N. Javed, M.Naseem and A. Ishtiaq. (2011): Length-weight, length-length relationship and feeding habits of wild Indus Mahseer, Tor marolepis, fom Attok, Pakistan. Journal of applied Ichthyology, 28 (2012), 673-676

[7] Md. Yeamin Hossain.(2010): Morphometric relationship of Length-weight and length-length of four cyprinid small Indigenous fish species from the Padma river (NW Bangladesh). Turkish journal of fisheries and aquatic sciences10: 131-134 (2010).

[8] Renjini P.K. \& Bijoy Nandan S.(2011): LengthWeight relationship, condition factor and morphometry of gold spot mullet Liza Parsia (Hamilton, 1822) from Cochin estuary. Indian journal of Geo-marine Sciences Vol.40 (4), August 2011,pp 567-571.

[9] Sharad C.Srivastava, Pankaj Verma, Kailash C.Yadavand Madhu Tripathi (2014): Feeding ecology of carp fishes and cat fishes captured from Gomati River stretch at Lucknow, Uttar Prades, India. International Journal of fauna and biological studies:1(5):65-68, 2014.

[10] T. Wang, H.S. Wang, G.W. Sun, D. Huang and J. H. Shen. (2012): Length- weight and length-length relationship for some Yangtze River fishes in Tian-ezhou Oxbow, China. Journal of applied Ichthyology.28 (2012), 660-662. 